\title{
Effects of the indoor environment on the fraction of exhaled nitric oxide in school-aged children
}

\author{
Thomas A Kovesi MD¹, Robert E Dales MD MSc²
}

TA Kovesi, RE Dales. Effects of the indoor environment on the fraction of exhaled nitric oxide in school-aged children. Can Respir J 2009;16(3):e13-e18.

BACKGROUND: The fractional concentration of exhaled nitric oxide (FeNO) appears to be a good marker for airway inflammation in children with asthma.

OBJECTIVE: To evaluate the effect of environmental exposures on exhaled nitric oxide in a community sample of children.

METHODS: The relationship among exhaled nitric oxide, underlying disease and home environmental exposures was examined using questionnaire data and measurement of exhaled nitric oxide in a cross-sectional study of 1135 children that included healthy children, and children with allergies and/or asthma who were attending grades 4 through 6 in Windsor, Ontario.

RESULTS: Among healthy children, there was a positive association between FeNO and occupancy $(\mathrm{P}<0.02)$. Compared with forced air and hot water radiant heat, electric baseboard heating was associated with a significant increase of $\mathrm{FeNO}$ in healthy children $(\mathrm{P}=0.007)$ and children with allergies $(\mathrm{P}=0.043)$. FeNO was not associated with environmental tobacco smoke exposure or reported surface mold. The presence of pet $\operatorname{dog}(\mathrm{s})$, but not cats, was associated with a significantly lower FeNO in healthy children $(\mathrm{P}<0.001)$ and in children with reported allergies $(\mathrm{P}<0.001)$.

CONCLUSIONS: The type of heating system, but not previously reported environmental tobacco smoke or mold exposure appears to affect exhaled nitric oxide in children. Exposure to different types of pets may have disparate effects on airway inflammation.

Key Words: Air Pollution; Allergens; Child; Indoor heating; Nitric oxide analysis

A human activity pattern survey conducted in North America reported that adults spend approximately $87 \%$ of their time in buildings (1). Indoor airborne irritants may potentially cause airway inflammation in any child (2). Indoor airborne allergens are known to trigger early- and late-phase allergic responses in children and adults with asthma, which may lead to upper and lower airway inflammation (2). Nitric oxide (NO) is synthesized by endothelial, epithelial and inflammatory cells in the airways through the action of $\mathrm{NO}$ synthetase on L-arginine (2). NO synthetase type II, one of the three isoforms of this enzyme, is an inducible form that is found in airway epithelial cells and inflammatory cells, and is induced by inflammatory cytokines (3). The fractional concentration of exhaled NO (FeNO) appears to be a useful indicator of airway inflammation, correlating with bronchial reactivity and serum eosinophil count, and decreasing with anti-inflammatory asthma therapy such as inhaled corticosteroids $(3,4)$. The present study investigated the influence of indoor environmental factors on airway inflammation, as measured by exhaled $\mathrm{NO}$ among school

\section{Effets des milieux ambiants sur la fraction d'oxyde nitrique expirée chez les enfants d'âge scolaire}

CONTEXTE : La concentration de la fraction d'oxyde nitrique expirée (FeNO) semble être un bon marqueur de l'inflammation respiratoire chez les enfants asthmatiques.

OBJECTIF : Évaluer l'effet de diverses expositions dans le milieu ambiant sur la FeNO chez des enfants d'un échantillon communautaire. MÉTHODES : Les auteurs ont analysé le lien entre l'oxyde nitrique expiré, la maladie sous-jacente et diverses expositions dans le milieu ambiant à la maison, à partir des données d'un questionnaire et des taux d'oxyde nitrique expiré mesurés dans le cadre d'une étude transversale regroupant 1135 enfants de la $4^{\mathrm{e}}$ à la $6^{\mathrm{e}}$ années, incluant des enfants en bonne santé et des enfants souffrant d'allergies et/ou d'asthme, de Windsor, en Ontario.

RÉSULTATS : Chez les enfants en bonne santé, on a noté un lien positif entre la FeNO et le milieu ambiant $(\mathrm{p}<0,02)$. Comparativement à la chaleur des systèmes à air pulsé ou à eau chaude, le chauffage par plinthes électriques a été associé à une augmentation significative de la FeNO chez les enfants en bonne santé $(p=0,007)$ et les enfants allergiques $(p=0,043)$. La FeNO n'a pas été associée à une exposition environnementale à la fumée de tabac ou à des moisissures de surface signalées. La présence de chiens, mais non de chats, a été associée à une FeNO significativement moindre chez les enfants en bonne santé $(p<0,001)$ et chez les enfants souffrant d'allergies avérées $(\mathrm{p}<0,001)$.

CONCLUSION : Le type de système de chauffage, mais non l'exposition à la fumée de tabac ou à des moisissures signalées dans l'environnement, semble affecter le taux d'oxyde nitrique expiré chez les enfants. L'exposition à différents types d'animaux de compagnie peut exercer des effets divers sur l'inflammation des voies respiratoires.

children in grades 4 to 6 in Windsor, Ontario. We hypothesized that a variety of indoor air contaminants would increase FeNO in children. We previously reported (5) that FeNO is affected by racial origin, age and height in the healthy portion of this community sample. The FeNO was higher in children of AsianCanadian ancestry and tended to be higher in children of African-Canadian ancestry than in Caucasians. There was a weak, positive association between $\mathrm{FeNO}$ and age or height. In addition, we have previously demonstrated that FeNO was significantly greater in children with reported asthma or allergies than in healthy children, and greater in children with asthma and reported allergies than children with asthma but no allergies (6).

\section{METHODS}

FeNO was measured as in the Windsor Childrens' Respiratory Health Study (5-7), which included school children nine to 12 years of age, attending grades 4 through 6 (inclusive) in Windsor, Ontario. Subjects were enrolled after written, informed

${ }^{1}$ Department of Pediatrics, Children's Hospital of Eastern Ontario, University of Ottawa; ${ }^{2}$ Biostatistics and Epidemiology Division, Health Canada, Ottawa, Ontario

Correspondence: Dr Thomas Kovesi, Department of Pediatrics, Children's Hospital of Eastern Ontario, 401 Smyth Road, Ottawa, Ontario

K1H 8L1. Telephone 613-737-7600 ext 2868, fax 613-738-4886, e-mail kovesi@cheo.on.ca 
consent from the caregiver was obtained. Consenting caregivers also completed a brief respiratory questionnaire. In most cases, the subjects' caregivers had also previously completed a comprehensive questionnaire about the indoor environment and their child's respiratory health using questions from the American Thoracic Society (ATS)-Division of Lung Disease (DLD)-78-C questionnaire, as part of an earlier phase of the Windsor Childrens' Respiratory Health Study (7). The study was approved by Health Canada's Research Ethics Board (Ottawa, Ontario).

Respiratory function testing was performed in the participants' schools by certified respiratory therapists. The therapists were not blinded to the participants' health status. Singlebreath on-line measures of $\mathrm{FeNO}$ were measured according to ATS/European Respiratory Society recommendations using an Eco Physics CLD 88sp chemiluminescence analyzer (Eco Medics AG, Switzerland) (3). Measurements were taken from a slow vital capacity manoeuvre at $50 \mathrm{~mL} / \mathrm{s}$, with the computerized FeNO concentration independently validated by analysis of the FeNO versus time slope for determination of FeNO concentration, as reported previously (5).

FeNO and data from the two questionnaires were linked using subject name and date of birth. Subjects who had valid FeNO measurements and who had completed the ATS-DLD questionnaire were included in the study. Participants were classified as being healthy, having allergies but no asthma, having asthma and allergies, or having asthma but no allergies on the basis of affirmative responses to the questions on the ATSDLD questionnaire indicating whether the child had ever been diagnosed with asthma and/or allergies by a physician (8). Correct classification of healthy subjects was verified by confirming that these individuals did not report asthma medication use. Because allergies were not confirmed by objective testing, only limited analyses were performed in children with allergies and/or asthma; statistically significant findings are presented separately at the end of the Results section. Occupancy was defined as the number of persons divided by the number of rooms in the home (excluding bathrooms).

Differences in continuous variables were analyzed using Student's $t$ tests for two independent groups of subjects, and one-way ANOVA when there were more than two groups. Significant differences between multiple groups were evaluated using the Scheffe's test. Differences in the frequencies of categorical variables were evaluated using $\chi^{2}$ tests. Multivariate analyses were performed using the general linear models procedure, with forward entry of variables and removal at a $\mathrm{P}<0.10$ (SPSS version 15.0, SPSS Inc, USA). Analyses were repeated with log-transformed FeNO but because the findings were very similar, results using nontransformed values are provided, except where otherwise indicated. A $\mathrm{P}<0.05$ was considered to be statistically significant.

\section{RESULTS}

There were 8325 eligible children in grades 4 through 6 . Valid consent was obtained for 2626 of these children. Acceptable and reproducible FeNO measurements and complete respiratory symptom questionnaire data were available for 1135 children. They were classified into four groups: healthy $(n=656)$, allergies without asthma $(n=254)$, asthma without allergies $(\mathrm{n}=81)$, and asthma and allergies $(\mathrm{n}=144)$. As previously reported (6), FeNO differed in these groups $(\mathrm{P}=0.002)$, with the greatest values observed in the allergy (mean $\pm[\mathrm{SE}]$ 18.1 \pm 1.13 parts per billion [ppb]) and the allergy and asthma groups $(22.9 \pm 1.97 \mathrm{ppb})$, and the lowest value seen in the healthy group $(14.0 \pm 0.52 \mathrm{ppb})$ (Table 1). FeNO was significantly greater in older than in younger children for healthy children $(\mathrm{P}<0.02)$. Asian-Canadians had the greatest $\mathrm{FeNO}$ of all groups $(\mathrm{P}<0.001)(5)$. There were no consistent associations between $\mathrm{FeNO}$ and sex, or income across groups.

Indoor environmental characteristics are presented in Table 2. Among healthy children, there was a positive association between $\mathrm{FeNO}$ and occupancy $(\mathrm{P}<0.02)$, although this relationship was not consistent across disease groups. Compared with forced air and hot water radiant heat, electric baseboard heating was associated with a significant increase of $\mathrm{FeNO}$ in healthy children $(\mathrm{P}=0.007)$ and, furthermore, an approximately $50 \%$ increase in $\mathrm{FeNO}$ in the group with allergies $(\mathrm{P}=0.043)$. FeNO was not associated with indoor smoking or the number of cigarettes reported to be smoked in the home. In univariate analyses of the relationship between cockroach infestation and FeNO, sample size limited comparisons from reaching statistical significance. However, in multivariate analysis including disease group and racial ancestry, cockroach infestation was significantly positively associated with FeNO $(\mathrm{P}=0.002)$; these relationships did not change when household income was added to the model (Table 2). FeNO was not related to reported visible surface mold exposure. $\mathrm{FeNO}$ was not associated with the type of house the child lived in, age of the house, use of a wood or gas stove, use of an air conditioner, use of a mechanical ventilator to bring fresh air into the house, or whether a garage was attached to the house (data not shown).

The associations between reported pets and FeNO are presented in Table 3. Dogs were associated with a significantly lower FeNO in healthy children $(\mathrm{P}<0.001)$ and in the group with reported allergies $(\mathrm{P}<0.001)$. Cats were not associated with $\mathrm{FeNO}$ concentrations. Pet birds were associated with a significantly lower $\mathrm{FeNO}$ in healthy children $(\mathrm{P}=0.003)$, but not in children with allergies and/or asthma. Pet hamsters were associated with a significantly lower FeNO in healthy children $(\mathrm{P}<0.001)$. When data from all subjects were pooled, the presence of pet mice or rats was associated with a significantly higher FeNO ( $\mathrm{P}=0.019)$ but the sample size was inadequate to permit subgroup analysis (data not shown). After adjusting for demographic variables that were associated with FeNO (racial ancestry and age), and for health category and reported animal fur allergy, dog ownership remained statistically significantly associated with a lower FeNO (Table 4).

\section{DISCUSSION}

In children with asthma, FeNO has been shown to be a more sensitive indicator of airway inflammation than spirometry (3). While a number of studies have suggested subject factors that can alter FeNO measurements obtained during standardized testing, such as recent exercise or respiratory tract infection, relatively few studies have been performed to investigate whether environmental factors can affect $\mathrm{FeNO}$ in children (9-11). We examined these issues in a relatively large number of children obtained from a population sample. Dog, hamster or bird ownership was associated with significantly lower FeNO 
TABLE 1

Fractional concentration of exhaled nitric oxide (parts per billion) by subject demographic characteristics

\begin{tabular}{|c|c|c|c|c|c|}
\hline \multirow[b]{2}{*}{ Characteristic } & \multirow[b]{2}{*}{$\begin{array}{l}\text { Category (classified by } \\
\text { population median or group) }\end{array}$} & \multirow[b]{2}{*}{ Healthy } & \multirow[b]{2}{*}{ Allergies } & \multicolumn{2}{|c|}{ Asthma } \\
\hline & & & & $\begin{array}{c}\text { Without } \\
\text { reported allergies }\end{array}$ & $\begin{array}{c}\text { With } \\
\text { reported allergies }\end{array}$ \\
\hline Age, years & $\leq 10.9$ & $9.8^{* *}(4.3,34.7)\{335\}$ & $11.1(4.5,50.5)\{136\}$ & $9.6(3.8,54.6)\{40\}$ & $10.3^{*}(3.2,60.9)\{74\}$ \\
\hline \multirow[t]{2}{*}{ Sex } & Male & $9.7(3.9,41.4)\{293\}$ & $12.7(4.4,53.0)\{124\}$ & $10.7(4.1,51.5)\{44\}$ & $13.6(3.6,67.1)\{84\}$ \\
\hline & Female & $9.7(4.3,37.0)\{363\}$ & $11.6(4.4,75.5)\{130\}$ & $9.1(3.7,59.2)\{37\}$ & $9.7(3.5,101.5)\{60\}$ \\
\hline \multirow[t]{2}{*}{ Racial ancestry } & Caucasian & $9.5(4.0,29.9)\{559\}$ & $11.1(4.4,52.2)\{224\}$ & $9.5(3.9,41.6)\{69\}$ & $10.9(3.5,76.2)\{129\}$ \\
\hline & African-Canadian & $6.9(3.5,88.5)\{22\}$ & $23.3(6.8,34.6)\{4\}$ & $10.5(4.6,42.2)\{5\}$ & $11.9(7.4,73.9)\{5\}$ \\
\hline \multirow[t]{2}{*}{ Household income, \$ } & $\leq 35,000$ & $9.7(4.3,32.1)\{280\}$ & $12.5(4.5,77.6)\{121\}$ & $12.9(4.2,55.0)\{42\}$ & $9.6(3.5,88.2)\{73\}$ \\
\hline & $>35,000$ & $9.6(3.9,43.0)\{185\}$ & $11.8(3.6,66.0)\{61\}$ & $9.5(3.8,63.6)\{21\}$ & $12.7(3.7,70.9)\{36\}$ \\
\hline
\end{tabular}

Data presented as median (5th percentile, 95th percentile) $\{n\} .{ }^{*} P<0.05 ;{ }^{*} P<0.005$

TABLE 2

Fractional concentation of exhaled nitric oxide (parts per billion) by characteristics of the home environment

\begin{tabular}{|c|c|c|c|c|c|}
\hline \multirow[b]{2}{*}{ Characteristic } & \multirow[b]{2}{*}{$\begin{array}{l}\text { Category (classified by } \\
\text { population median or group) }\end{array}$} & \multirow[b]{2}{*}{ Healthy } & \multirow[b]{2}{*}{ Allergies } & \multicolumn{2}{|c|}{ Asthma } \\
\hline & & & & $\begin{array}{c}\text { Without } \\
\text { reported allergies }\end{array}$ & $\begin{array}{c}\text { With } \\
\text { reported allergies }\end{array}$ \\
\hline $\begin{array}{l}\text { Occupancy (number of } \\
\text { persons per room in the } \\
\text { home [excluding bath- } \\
\text { rooms]) }\end{array}$ & $\leq 0.54$ & $9.5^{*}(4.2,29.3)\{314\}$ & $12.5(4.2,65.4)\{139\}$ & $11.3^{*}(4.2,51.5)\{44\}$ & $10.7(3.6,77.0)\{76\}$ \\
\hline \multirow[t]{2}{*}{ Heating type } & Forced air & $9.6^{*}(4.3,35.0)\{555\}$ & $11.8^{*}(4.6,58.0)\{211\}$ & $11.2(4.1,54.7)\{69\}$ & $11.1(3.7,79.0)\{127\}$ \\
\hline & Hot water radiator & $8.9(3.4,31.9)\{22\}$ & $11.1(3.5,41.8)\{12\}$ & $8.2(6.3,17.7)\{4\}$ & $8.7(3.5,70.0)\{10\}$ \\
\hline \multirow[t]{2}{*}{ Cigarette smoke exposure } & Absent & $9.9(4.0,38.6)\{516\}$ & $11.9(4.5,71.4)\{214\}$ & $9.9(3.9,50.0)\{67\}$ & $11.1(3.5,70.0)\{119\}$ \\
\hline & Present & $9.0(4.5,41.2)\{135\}$ & $11.9(4.2,66.2)\{38\}$ & $13.9(4.2,55.2)\{14\}$ & $13.5(3.9,80.2)\{24\}$ \\
\hline \multirow[t]{2}{*}{ Cockroach infestation } & Absent & $9.7(4.2,38.1)\{646\}$ & $12.0(4.4,67.0)\{253\}$ & $10.0(4.0,43.5)\{80\}$ & $11.1(3.6,69.7)\{141\}$ \\
\hline & Present & $13.7(5.6,52.0)\{10\}$ & 53.0 (none) $\{1\}$ & 95.3 (none) $\{1\}$ & $22.4(9.6,102.8)\{3\}$ \\
\hline Mold exposure & Absent & $9.9(4.4,40.0)\{466\}$ & $13.3(4.8,69.6)\{152\}$ & $9.5(3.9,36.4)\{49\}$ & $13.0(3.6,68.7)\{87\}$ \\
\hline
\end{tabular}

Data presented as median (5th percentile, 95th percentile) $\{n\} .{ }^{*} P<0.05 ;{ }^{*} P<0.005$

TABLE 3

Fractional concentration of exhaled nitric oxide (parts per billion) by reported pet exposure

\begin{tabular}{|c|c|c|c|c|c|}
\hline \multirow[b]{2}{*}{ Pet type } & \multirow[b]{2}{*}{ Exposure } & \multirow[b]{2}{*}{ Healthy } & \multirow[b]{2}{*}{ Allergies } & \multicolumn{2}{|c|}{ Asthma } \\
\hline & & & & Without reported allergies & With reported allergies \\
\hline \multirow[t]{2}{*}{ Dog } & Absent & $10.2^{\star *}(4.4,43.1)\{455\}$ & $13.2^{* *}(4.5,73.7)\{181\}$ & $11.2(4.1,54.9)\{65\}$ & $13.4(3.7,70.8)\{95\}$ \\
\hline & Present & $8.5(3.6,28.1)\{201\}$ & $10.8(4.1,34.4)\{73\}$ & $9.4(3.7,37.2)\{16\}$ & $9.5(3.5,88.5)\{49\}$ \\
\hline \multirow[t]{2}{*}{ Cat } & Absent & $9.9(4.1,41.8)\{490\}$ & $12.9(4.8,71.7)\{171\}$ & $10.3(3.9,57.9)\{54\}$ & $11.9(3.5,71.2)\{97\}$ \\
\hline & Present & $8.7(4.3,30.1)\{166\}$ & $10.8(4.2,60.7)\{83\}$ & $9.5(4.0,48.3)\{27\}$ & $11.1(3.8,86.3)\{47\}$ \\
\hline \multirow[t]{2}{*}{ Bird } & Absent & $9.8^{* *}(4.2,40.4)\{606\}$ & $12.1(4.6,66.3)\{238\}$ & $10.3(4.1,54.4)\{74\}$ & $11.1(3.5,75.6)\{135\}$ \\
\hline & Present & $8.5(4.0,28.2)\{50\}$ & $12.4(3.5,69.0)\{16\}$ & $7.6(3.4,37.2)\{7\}$ & $19.5(4.2,62.7)\{9\}$ \\
\hline
\end{tabular}

Data presented as median (5th percentile, 95th percentile) $\{n\} .{ }^{*} P<0.05 ;{ }^{*} P<0.005$

concentrations. Reported pet mice or rat ownership, cockroach infestation and electric baseboard heating were associated with a significant increase in FeNO. No association was observed between FeNO and reported cat ownership, environmental tobacco smoke exposure, home dampness or molds. Reported animal fur allergy was associated with an increase in FeNO, independent of reported pet ownership.

Our findings suggest that different animal allergens may have differential effects on allergic inflammation and/or FeNO. Exposure to furred pets may have a dichotomous effect on atopy, depending on the age when exposure occurred. According to the 'hygiene hypothesis', certain early life exposures shift the developing immune system from a cell-mediated, T-helper cell type 1 predominant state to being more predominantly antibodymediated T-helper cell type 2 state, increasing the risk of subsequent atopic disease (12). The effect of exposure to furred pets is possibly mediated by increased exposure to endotoxin $(13,14)$. Early exposure to cats or dogs has been associated with both an increase or decrease in the risk of subsequent allergy (15). Because our study was cross-sectional, we could not assess the potential effects of duration or onset of exposure on FeNO; the effects of early life exposure may be particularly important (13). We found no significant difference in the frequency of dog ownership among disease classes $(\mathrm{P}=0.14)$ but a difference in frequency of cat ownership among the disease classes approached significance $(\mathrm{P}=0.06)$ and cat ownership was 


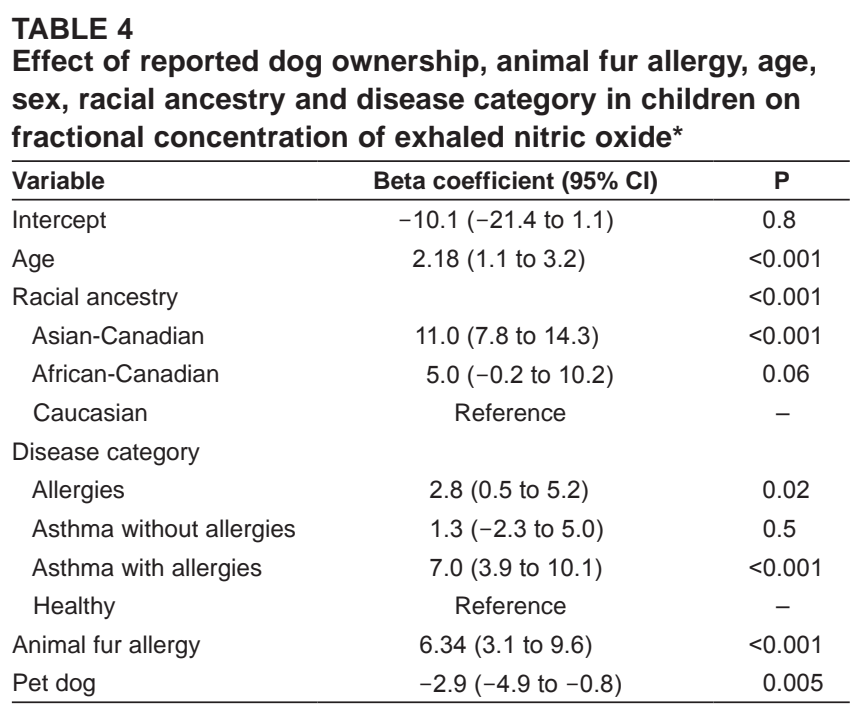

*General linear models procedure

significantly more common among children with allergies and asthma, or allergies alone than in healthy children $(\mathrm{P}=0.046$ and $\mathrm{P}=0.016$, respectively; data not shown). The presence of family members with pre-existing allergies may discourage families from purchasing pets (16); conversely, animal ownership could increase the risk of sensitization (17). Any potential differential avoidance of household pets would not alter the relationship between reported pet ownership and children's measured FeNO.

Spanier et al (18) reported that in children with asthma, sensitization to dogs was associated with increased FeNO, but there was no association between exposure to dogs and $\mathrm{FeNO}$, and there was no interaction between sensitization and exposure. We also found that while animal sensitization was associated with increased $\mathrm{FeNO}$, dog exposure was generally associated with a reduction in FeNO concentration. Children with allergies have been reported to have increased FeNO concentrations (4). Langley et al (17) reported that adults with asthma who were not sensitized to dogs had significantly higher FeNO concentrations when exposed to high levels of dog allergen, but only before adjustment for other factors. As observed with dogs, we observed that hamster ownership was associated with a reduction in FeNO. It is possible that dog and hamster exposure reduce the risk of eosinophilic inflammation in healthy children in accordance with the hygiene hypothesis. Unlike Spanier et al (18), who studied children with asthma, we also evaluated healthy children. The stimulatory effects of dog exposure previously reported in dog-sensitized children with asthma may override any inhibitory effects on FeNO resulting from exposure to indoor microbes or microbial products associated with dog ownership $(13,14,18)$. In contrast, there was a significant association between $\mathrm{FeNO}$ and pet rat or mice exposure. This could potentially reflect eosinophilic inflammation associated with pet rat or mice ownership. Rat urine has also been recognized as a significant occupational sensitizer (19).

Janson et al (20) noted that FeNO concentrations were increased in children sensitized to cats who were exposed to pets at home. Spanier et al (18) also found that cat sensitization was associated with increased $\mathrm{FeNO}$, but cat exposure tended to be associated with a reduced FeNO concentration. There was no significant interaction between sensitization and exposure. In adults with cat sensitization, FeNO did not change significantly with cat exposure $(17,21)$. We also found that cat ownership was not associated with a change in FeNO.

Cockroach exposure can cause worsening asthma in children with asthma living in inner city areas (22). Spanier et al (18) found that cockroach sensitization was associated with elevated FeNO concentrations, but there was no association between exposure and $\mathrm{FeNO}$, and no interaction between sensitization and exposure. In a multiple linear regression model, we also found that reported cockroach exposure was associated with increased FeNO concentrations. It is unclear whether this was due to allergic inflammation or other toxic products released by cockroaches (23).

Although tobacco smoke is clearly an airway irritant in both healthy individuals and individuals with asthma, active cigarette smoking is known to reduce FeNO concentrations, possibly by downregulation of NO synthetase (24). Similarly, most previous studies did not find that $\mathrm{FeNO}$ in children is altered by passive smoke exposure $(18,25)$, although Franklin et al (26) reported that parental smoking increased FeNO in young children. In accordance with most previous reports, we found no effect of environmental cigarette exposure on FeNO, and no differential effects of passive cigarette exposure were seen in the different disease categories.

Numerous factors related to housing, including mold and gaseous air pollutant exposure, have been associated with airway inflammation in children (27-29). Delfino et al (29) reported that outdoor, but not indoor, nitrogen dioxide levels were associated with an increased FeNO concentration in children with asthma. We found no evidence that housing factors, other than the main heating system, were associated with altered FeNO. While these factors may not have an important effect on airway inflammation, it is also possible that FeNO is an inadequately sensitive indicator of any actual effects, and/or measurement of indoor air pollutants may be necessary to detect such effects (30). We found a significant relationship between $\mathrm{FeNO}$ and occupancy. Increased household occupancy is associated with elevation of various airborne contaminants, including dust mite and cockroach allergens, which may increase the risk of airway inflammation (31).

Few studies have evaluated the potential effect of home heating or cooling systems on airway inflammation. InfanteRivard (32) did report that asthma was more common in children living in houses with electric heating. Consistent with this, we found that electric baseboard heating was associated with a higher FeNO. Arbes et al (33) reported that forced air heating was associated with lower indoor dust mite levels. It is possible that the increased levels of indoor dust mite associated with electric heating increase the likelihood of allergic sensitization and FeNO. Dust mite allergen concentrations have been found to correlate with FeNO concentrations in children with asthma (18). In addition, Gilbert et al (34) found that electric baseboard heating is associated with higher formaldehyde concentrations in homes, which, in turn, has been associated with increased FeNO concentrations in children $(28,34)$. Neither formaldehyde concentrations nor dust mite levels were measured in our study. Initiation of seasonal forced air heating was not associated with asthma symptoms in a previous 
Canadian study (35). Spanier et al (18) reported no significant relationship between $\mathrm{FeNO}$ in environmental tobacco-exposed children with asthma and home heating or cooling method, house volume or occupancy relative to house volume. While we found no relationship between reported home dampness or visible mold, reported window pane condensation has been associated with $\mathrm{FeNO}$ in nonallergic children in a study by Janson et al (20). Indoor mold levels likely differed between this Swedish study and our study in southern Ontario.

Our study had a number of strengths and limitations. We studied a community sample of children rather than the more commonly studied clinical sample. Although there may be a volunteer bias, we avoided further selection influences that occur when subjects have been referred to a clinical setting. There may be misclassification on diagnoses, but we relied on the reported diagnosis of asthma and allergies by a physician, as described in previous reports $(21,36)$. For the categorization of allergies with or without asthma, it would be preferable to confirm atopy using allergy skin testing, as had been performed in previous, somewhat smaller studies $(2,37,38)$. Unfortunately, The ATS-DLD questionnaire does not differentiate between cat and dog allergies; consequently, the relationships between dog or cat exposure and reported animal allergy could not be evaluated precisely. Random misclassification on 'allergy' would reduce the observed estimate of effect but our large sample size would increase the power to detect a real effect. Correction classification of our subjects is further suggested by the fact that FeNO concentrations were significantly higher in children with reported asthma or allergies than in healthy children (one-way ANOVA $\mathrm{P}<0.002$ ), and was greater in children with asthma and reported allergies than in children with asthma but no allergies $(\mathrm{P}=0.022)$. Similarly, exposures, such as indoor endotoxin or allergen concentrations, were not measured directly, although previous work has validated questionnairebased research (eg, for estimating indoor mold and cigarette exposure) $(30,39)$. We compared study participants with children who completed the detailed respiratory questionnaire the previous fall but who did not undergo FeNO measurement $(\mathrm{n}=3399)$. There were no significant differences in age, sex, wheezing symptoms (data available on request) or reported current asthma (11.3\% in nonparticipants versus $11.1 \%$ in participants). However, nonparticipants were significantly less likely to be Caucasian $(68.6 \%$ versus $74.2 \% ; \mathrm{P}=0.003)$ or have pets (49.2\% versus $54.3 \% ; \mathrm{P}=0.0052)$ and they were significantly more likely to have a family income below $\$ 35,000$ CAD $(18.4 \%$ versus $12.3 \% ; \mathrm{P}<0.001)$, or have at least one smoker (26.0\% versus $19.4 \% ; \mathrm{P}<0.001)$. Thus, nonparticipants appeared to more likely to have a lower reported family income. Although this may reduce the external generalizability of our

\section{REFERENCES}

1. Klepeis NE, Nelson WC, Ott WR, et al. The National Human Activity Pattern Survey (NHAPS): A resource for assessing exposure to environmental pollutants. J Expo Anal Environ Epidemiol. 2001;11:231-52.

2. Franklin PJ, Taplin R, Stick SM. A community study of exhaled nitric oxide in healthy children. Am J Respir Crit Care Med 1999;159:69-73.

3. American Thoracic Society/European Resipiratory Society recommendations for standardized procedures for the online and offline measurement of exhaled lower respiratory nitric oxide and nasal nitric oxide, 2005. Am J Respir Crit Care Med 2005;171:912-30. findings to the general population, it would not affect the internal validity of the study findings, which are contrasts between groups. A post hoc analysis was performed to evaluate the potential effect of the season of testing, classifying testing date as 'winter' (February and March) or 'spring' (April to June) based on usual pollen levels (40). FeNO was not significantly higher in the spring than in the winter for the entire study population and in the various disease subgroups (data not presented). Season could affect allergen exposure both by modifying airborne concentrations of outdoor allergens and the proportion of time subjects spend indoors or outdoors. A history of asthma was reported by $19.8 \%$ of our subjects, and $22.3 \%$ had a reported history of allergies. These proportions are very similar to previous findings in southern Ontario. Habbick et al (41) found that $19.2 \%$, and $27.7 \%$ of children 13 to 14 years of age in Hamilton, Ontario, had a reported history of asthma (ever), and hay fever (ever), respectively. Because our study was designed to be hypothesis-generating, correction for multiple comparisons was not performed. As we have previously reported for this population, our multivariate analyses nearly always indicated that FeNO was altered by racial origin and disease category, although minor inconsistencies occurred due to variation in the number of subjects in each cohort in the different models.

\section{CONCLUSION}

In a large population-based sample of school-aged children, FeNO appears to be altered by a variety of factors, sometimes in rather unexpected ways. Furred pet exposure generally decreased FeNO. Cockroach exposure and electric baseboard heating were associated with increased FeNO. Other household factors, including passive cigarette smoke exposure and reported home dampness and mold exposure, had no significant effect on FeNO. Further studies to confirm and expand these findings are required.

ACKNOWLEDGEMENTS: The authors acknowledge, with gratitude, the Centre for Environmental Health of Ontario, The City of Windsor School Boards, The Windsor community parents and children, The Windsor Medical Officer of Health, The Essex County Health Unit, The University of Windsor, Environment Canada, The Ministry of the Environment, The United States Environmental Protection Agency, and The International Joint Commission. We thank Ryan Kulka, Air Health Effects Division, Health Canada, for coordinating the NO analyses. We thank Dr Eugeniusz Porada who independently verified the automated scoring of the FeNO data and $\mathrm{Dr} \mathrm{Li}$ Chen for her assistance with the statistical analysis.
4. Jouaville LF, Annesi-Maesano I, Nguyen LT, Bocage AS, Bedu M, Caillaud D. Interrelationships among asthma, atopy, rhinitis and exhaled nitric oxide in a population-based sample of children. Clin Exp Allergy 2003;33:1506-11.

5. Kovesi T, Kulka R, Dales R. Exhaled nitric oxide concentration is affected by age, height, and race in healthy 9- to 12-year-old children. Chest 2008;133:169-75.

6. Kovesi T, Dales R. Exhaled nitric oxide and respiratory symptoms in a community sample of school aged children. Pediatr Pulmonol 2008;43:1198-205.

7. Dales RE, Liu L, Wheeler A, Frescura A-M, Fortier E. Windsor 
Children's Respiratory Health Study. Healthy Environments and Consumer Safety Branch, Health Canada. <http://www.epa.gov/dears/ international/frescura.pdf $>$ (Version current at April 14, 2009).

8. Ferris BG. Epidemiology Standardization Project (American Thoracic Society). Am Rev Respir Dis 1978;118:1-120.

9. Verges S, Tonini J, Flore P, Favre-Juvin A, Levy P, Wuyam B. Exhaled nitric oxide in single and repetitive prolonged exercise. J Sports Sci 2006;24:1157-63.

10. Gentile DA, Doyle WJ, Belenky S, Ranck H, Angelini B, Skoner DP. Nasal and oral nitric oxide levels during experimental respiratory syncytial virus infection of adults. Acta Otolaryngol 2002;122:61-6.

11. Olin AC, Aldenbratt A, Ekman A, et al. Increased nitric oxide in exhaled air after intake of a nitrate-rich meal. Respir Med 2001;95:153-8.

12. Maziak W. The asthma epidemic and our artificial habitats. BMC Pulm Med 2005;5:5.

13. Braun-Fahrlander C, Riedler J, Herz U, et al. Environmental exposure to endotoxin and its relation to asthma in school-age children. N Engl J Med 2002;347:869-77.

14. Waser M, von ME, Riedler J et al. Exposure to pets, and the association with hay fever, asthma, and atopic sensitization in rural children. Allergy 2005;60:177-84.

15. Simpson A, Custovic A. Early pet exposure: Friend or foe? Curr Opin Allergy Clin Immunol 2003;3:7-14.

16. Hansel NN, Eggleston PA, Krishnan JA, et al. Asthma-related health status determinants of environmental control practices for inner-city preschool children. Ann Allergy Asthma Immunol 2006;97:409-17.

17. Langley SJ, Goldthorpe S, Craven M, Woodcock A, Custovic A. Relationship between exposure to domestic allergens and bronchial hyperresponsiveness in non-sensitised, atopic asthmatic subjects. Thorax 2005;60:17-21.

18. Spanier AJ, Hornung R, Lierl M, Lanphear BP. Environmental exposures and exhaled nitric oxide in children with asthma. J Pediatr 2006;149:220-6.

19. Heederik D, Venables KM, Malmberg P, et al. Exposure-response relationships for work-related sensitization in workers exposed to rat urinary allergens: Results from a pooled study. J Allergy Clin Immunol. 1999;103:678-84.

20. Janson C, Kalm-Stephens P, Foucard T, Norback D, Alving K, Nordvall SL. Exhaled nitric oxide levels in school children in relation to IgE sensitisation and window pane condensation. Respir Med 2005;99:1015-21.

21. Malinovschi A, Janson C, Holmkvist T, Norback D, Merilainen P, Hogman M. IgE sensitisation in relation to flow-independent nitric oxide exchange parameters. Respir Res 2006;7:92.

22. Turyk M, Curtis L, Scheff P, et al. Environmental allergens and asthma morbidity in low-income children. J Asthma 2006;43:453-7.

23. Page K, Hughes VS, Bennett GW, Wong HR. German cockroach proteases regulate matrix metalloproteinase- 9 in human bronchial epithelial cells. Allergy 2006;61:988-95.

24. Yates DH, Breen H, Thomas PS. Passive smoke inhalation decreases exhaled nitric oxide in normal subjects. Am J Respir Crit Care Med 2001;164:1043-6.
25. Dinakar C, Lapuente M, Barnes C, Garg U. Real-life environmental tobacco exposure does not affect exhaled nitric oxide levels in asthmatic children. J Asthma 2005;42:113-8.

26. Franklin PJ, Turner S, Mutch R, Stick SM. Parental smoking increases exhaled nitric oxide in young children. Eur Respir J 2006;28:730-3

27. Dales RE, Miller D. Residential fungal contamination and health: Microbial cohabitants as covariates. Environ Health Perspect 1999;107(Suppl 3):481-3.

28. Franklin P, Dingle P, Stick S. Raised exhaled nitric oxide in healthy children is associated with domestic formaldehyde levels. Am J Respir Crit Care Med 2000;161:1757-9.

29. Delfino RJ, Staimer N, Gillen D, et al. Personal and ambient air pollution is associated with increased exhaled nitric oxide in children with asthma. Environ Health Perspect 2006;114:1736-43.

30. Dales RE, Miller D, McMullen E. Indoor air quality and health: Validity and determinants of reported home dampness and moulds. Int J Epidemiol 1997;26:120-5.

31. Leaderer BP, Belanger K, Triche E, et al. Dust mite, cockroach, cat, and dog allergen concentrations in homes of asthmatic children in the northeastern United States: Impact of socioeconomic factors and population density. Environ Health Perspect 2002;110:419-25.

32. Infante-Rivard C. Childhood asthma and indoor environmental risk factors. Am J Epidemiol 1993;137:834-44.

33. Arbes SJ Jr, Cohn RD, Yin M, et al. House dust mite allergen in US beds: Results from the First National Survey of Lead and Allergens in Housing. J Allergy Clin Immunol 2003;111:408-14.

34. Gilbert NL, Gauvin D, Guay M, et al. Housing characteristics and indoor concentrations of nitrogen dioxide and formaldehyde in Quebec City, Canada. Environ Res 2006;102:1-8.

35. Dales RE, Fyfe M, Schweitzer I. Does forced air heating exacerbate asthma? J Allergy Clin Immunol 1992;90:803-7.

36. Olin AC, Rosengren A, Thelle DS, Lissner L, Bake B, Toren K. Height, age, and atopy are associated with fraction of exhaled nitric oxide in a large adult general population sample. Chest 2006;130:1319-25.

37. Steerenberg PA, Janssen NA, de Meer G, et al. Relationship between exhaled $\mathrm{NO}$, respiratory symptoms, lung function, bronchial hyperresponsiveness, and blood eosinophilia in school children. Thorax 2003;58:242-5.

38. Malmberg LP, Petays T, Haahtela T, et al. Exhaled nitric oxide in healthy nonatopic school-age children: Determinants and heightadjusted reference values. Pediatr Pulmonol 2006;41:635-42.

39. Gehring U, Leaderer BP, Heinrich J, et al. Comparison of parental reports of smoking and residential air nicotine concentrations in children. Occup Environ Med 2006;63:766-72.

40. Aerobiology Research Laboratories. Aerobiology Research Laboratories - Allergen update: Windsor Ontario - Predominant Pollen. Aerobiology Research Laboratories. <http://www.pollenplus. com/allergen-update/site-info/windsor.html $>$ (Version current at March 3, 2006).

41. Habbick BF, Pizzichini MM, Taylor B, Rennie D, Senthilselvan A, Sears MR. Prevalence of asthma, rhinitis and eczema among children in 2 Canadian cities: The International Study of Asthma and Allergies in Childhood. CMAJ 1999;160:1824-8. 


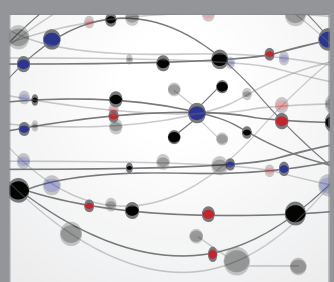

The Scientific World Journal
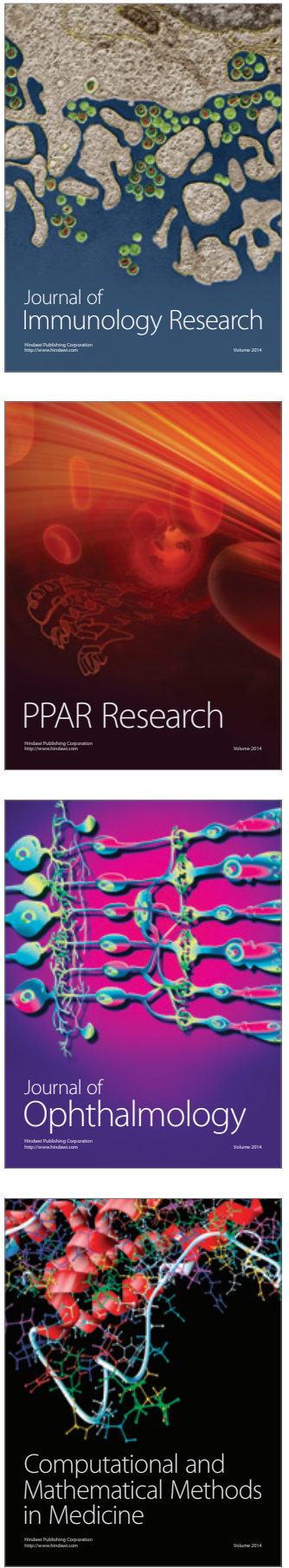

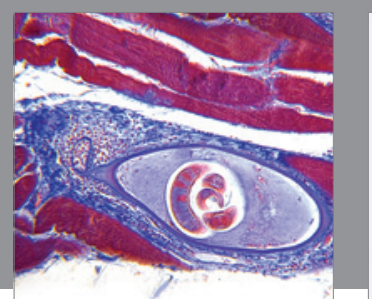

Gastroenterology Research and Practice

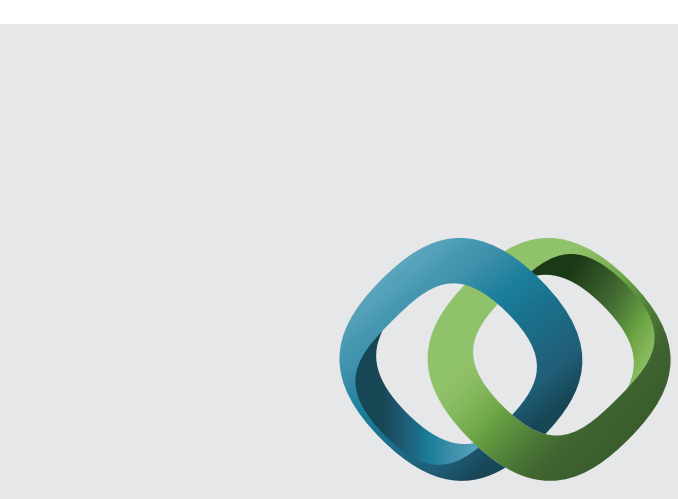

\section{Hindawi}

Submit your manuscripts at

http://www.hindawi.com
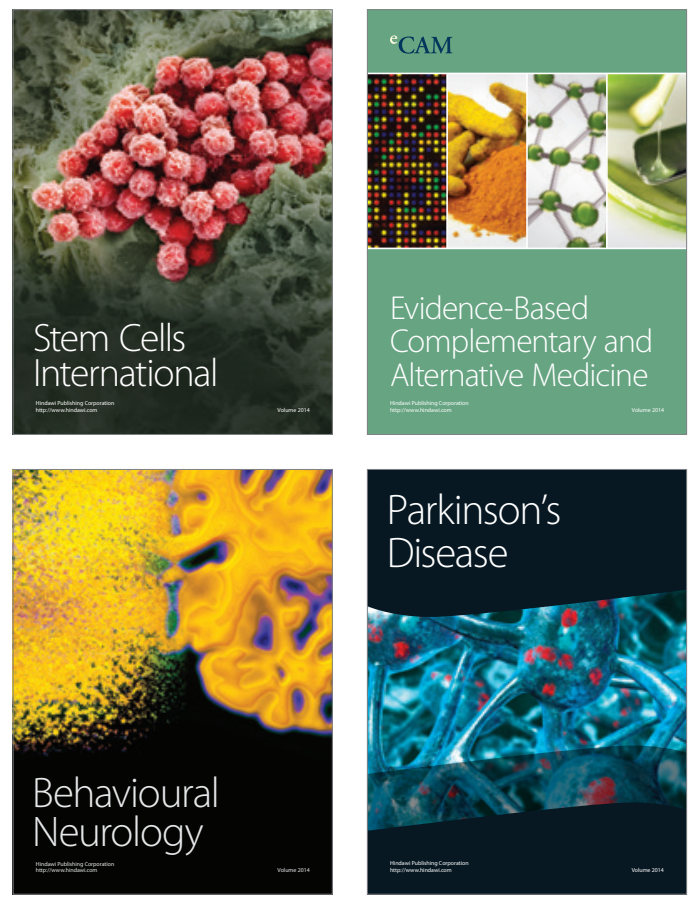
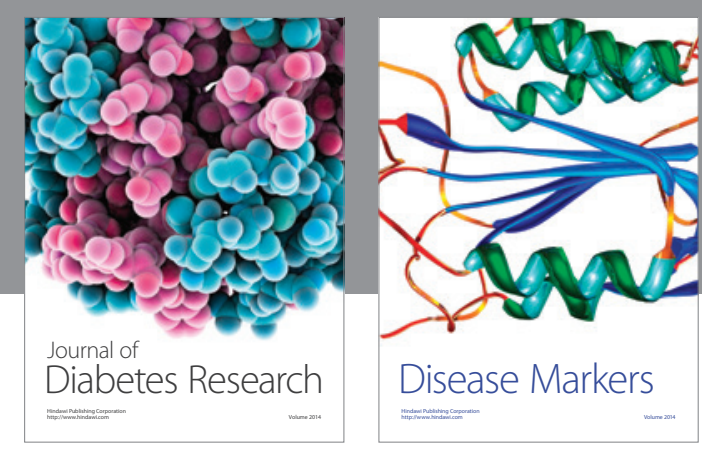

Disease Markers
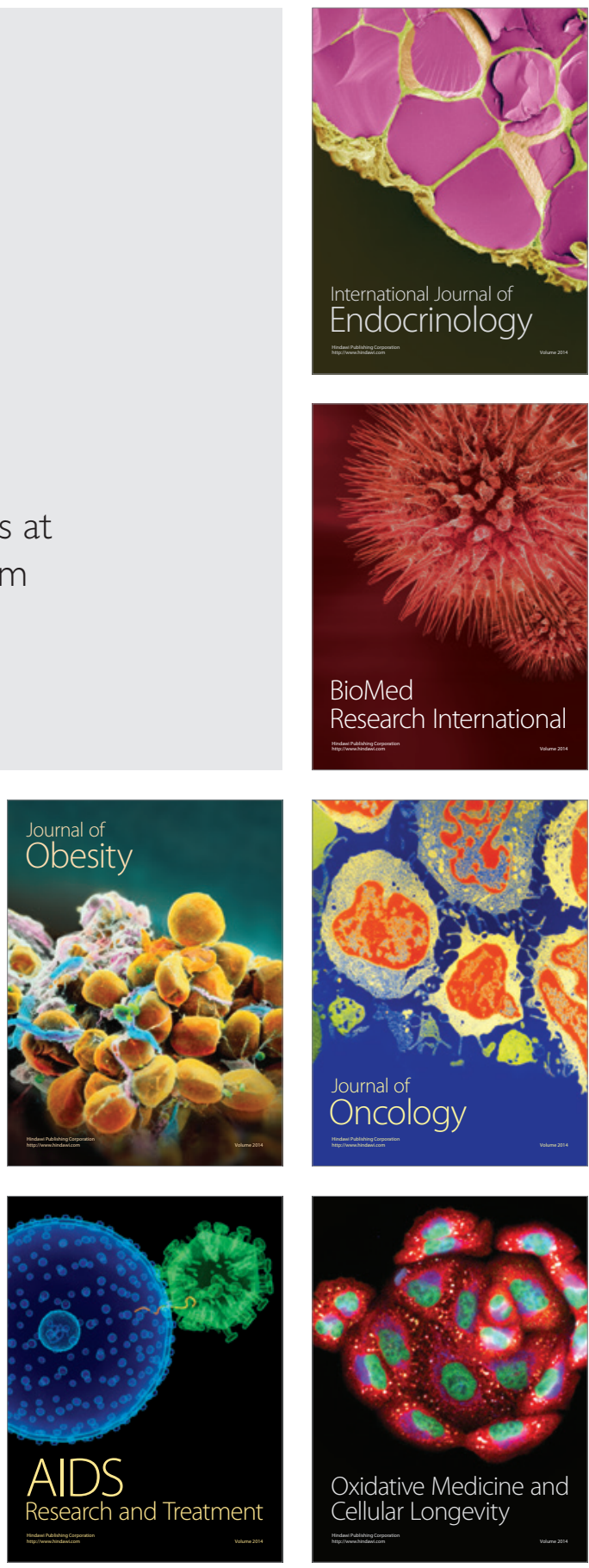